\title{
Endocrine Changes During Group Housing of Primiparous Sows in Early Pregnancy
}

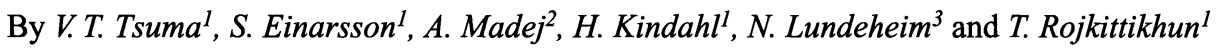 \\ ${ }^{1}$ Department of Obstetrics and Gynaecology, ${ }^{2}$ Department of Physiology, ${ }^{3}$ Department of Anımal Breedıng and \\ Genetıcs, Swedish Unıversity of Agricultural Sciences, Uppsala. Sweden.
}

\begin{abstract}
Tsuma, V.T., S. Einarsson, A. Madej, H. Kindahl, N. Lundeheim and T. Rojkittikhun: Endocrine changes during group housing of primiparous sows in early pregnancy. Acta vet. scand. 1996, 37, 481-490. - The effect of group housing sows during early pregnancy on maternal endocrine changes and on embryonic survival was studied Twenty crossbred (Swedısh Yorkshıre $\times$ Swedish Landrace) primiparous sows were used. On day $11 \pm 1$ of pregnancy 3 unacquainted sows were randomly assigned to a single pen measurıng $3 \mathrm{~m} \times 3 \mathrm{~m}$ in area. A fourth sow in each group was housed in an individual pen and used as a control. This procedure was repeated 5 times to collect data from 5 anımals in each rank as well as in a control group. Blood samples were collected from the day before grouping to day 5 after grouping for cortısol, corticosteroid-binding globulın $(\mathrm{CBG})$, progesterone $\left(\mathrm{P}_{4}\right)$, oestradıol-17 $\beta\left(\mathrm{E}_{2}\right)$ and prostaglandin $\mathrm{F}_{2 \alpha}$ metabolite (PG-metabolite) analysis. A rank-order test and an ACTH test were performed on day 4 and day 5 of grouping respectively. The sows were slaughtered on day $17 \pm 1$ of pregnancy and embryos recovered. Aggression accompanied by elevations $(p<0.05)$ in cortisol concentrations occurred in all grouped sows on the first day of grouping. The cortisol increase was greater $(\mathrm{p}<0.01)$ in the subordinate than in the other ranked sows. Cortisol concentrations and the level of aggression decreased on subsequent days during grouping, but the cortısol levels were still higher than on the pre-grouping day except for the intermediate ranked sows. Cortisol concentrations after the ACTH test were similar in the grouped as well as the control sows. The dominance hierarchy was confirmed during the rank order test. Concentrations of $\mathrm{P}_{4}, \mathrm{E}_{2}$, PG-metabolite and CBG were similar between the group-housed sows and with the controls. Mean embryonic recovery was $66.8 \% \pm 11.5 \%, 71.3 \% \pm 6.0 \%, 70.0 \% \pm 16.0 \%$, and $69.9 \% \pm 5.8 \%$ for the dominant, intermediate, subordınate, and control sows respectıvely. Hence, group housing during early pregnancy did not influence reproductive hormones or embryonic survival.
\end{abstract}

hormones; rank order.

\section{Introduction}

Group housing of sows is becoming a commonly used housing method in modern pig production due to welfare considerations. Although group housing may reduce problems of behavioural and social deprivation, it leads to increased aggression among the grouped sows (Bokma \& Kersjes 1988). Exposure to social stress is accompanied by disruption of reproduction in many mammalian species, and the degree of reproductive inhibition varies with social rank in animals which establish dominance hierarchies (Christian \& Davis 1964, Christian 1970). Previous work in pigs has shown that group housing during early pregnancy may negatively influence litter size at 
birth (Bokma 1990). Nevertheless, there is limited information concerning the effect of group housing during early pregnancy on reproductive performance. Aggression accompanied by increases in plasma corticosteroids occurs when unfamiliar pigs are placed together (Arnone \& Dantzer 1980, Warriss \& Brown 1985, Parrott \& Misson 1989). Stress may negatively affect pregnancy, with the period around implantation considered to be quite sensitive to the negative effects of stress (Moberg 1985). In the golden hamster, social stress during early pregnancy was associated with reduced litter size in the subordinate females (Pratt \& Lisk 1989). This reduction in litter size in the golden hamster has been shown to be mediated via glucocorticoids (Pratt \& Lisk 1990). The aim of the present study was to determine the endocrine changes and effect on embryonic survival, of grouping primiparous sows during early pregnancy.

\section{Materials and methods \\ Animals}

Experiments were performed with twenty crossbred (Swedish Yorkshire $\times$ Swedish Landrace) primiparous sows in 5 groups of 4 sows each. They were housed in individual pens and fed according to the Swedish breeding stock standard (Göransson 1984). Concentrates were provided twice daily (7:00 am and 3:00 pm) and straw once a day, with free access to water. The sows were fitted with jugular vein catheters (Rodriguez \& Kunavongkrit 1983) four days before weaning. Piglets were weaned after 5 weeks of lactation. Oestrous behaviour was checked for twice daily (9:00 am and 4:00 pm) with the aid of a boar. During oestrus (standing to back pressure in the presence of a boar) the sows were bred twice by artificial insemination (AI), using fresh semen ( 0 to 3 days old) from boars with known fertility. The sows found in oestrus in the morning were inseminated on the evening of the same day and in the morning of the next day. The sows found in oestrus in the evening were inseminated in the morning and evening of the next day. At 09:30 am on day 11 \pm 1 of pregnancy $\left(1^{\text {st }}\right.$ day of $\mathrm{AI}=$ day 1$)$ three unacquainted sows were randomly assigned to a single solid floor pen measuring $3 \mathrm{~m} \times 3 \mathrm{~m}$ in area. Each pen had 3 adjacent feeding troughs equipped with water nipples. The troughs were not divided by any crates, enabling sows to displace each other during feeding. The sows remained in this group until slaughter. The fourth sow in each group was housed in an individual pen as a control. To confirm the dominance hierarchy a rank-order test was performed on day 4 of grouping by providing small amounts of concentrates repeatedly 10 times. Social status was assigned based on the order by which the sows displaced each other from the feeding troughs. An adrenocorticotrophic hormone (ACTH) challenge test was performed at 9:00 am on day 5 of grouping by intravenous administration of $50 \mathrm{IU}$ ACTH (Acton prolongatum ${ }^{\circledR}$, Ferring AB, Sweden), to examine adrenal activity. The sows were slaughtered on day $17 \pm 1$ of pregnancy, ovulation rate determined and embryos recovered.

\section{Blood Collection}

The experimental design was approved by The Ethical Committee for Animal Experiments, Uppsala, Sweden. Blood samples were collected via permanent indwelling jugular catheters every $3 \mathrm{~h}$ (9:00 am to 9:00 pm) from the day before grouping to day 5 of grouping. On the day of the ACTH test, additional samples $(5 \mathrm{ml})$ were collected every $15 \mathrm{~min}$ (8:00 am to $12: 00 \mathrm{am})$ and then every one $\mathrm{h}(1: 00 \mathrm{pm}$ to 3:00 pm). Ten $\mathrm{ml}$ blood was collected in heparin tubes, centrifuged and plasma collected and stored at $-20^{\circ} \mathrm{C}$ until assayed for cortisol, corticosteroid-binding globulin (CBG), proges- 
terone $\left(\mathrm{P}_{4}\right)$, oestradiol-17 $\beta\left(\mathrm{E}_{2}\right)$ and the prostaglandin $\mathrm{F}_{2 \alpha}$ metabolite (PG-metabolite). Cortisol and PG-metabolite concentrations were determined in all samples, CBG in all 9:00 am samples, and progesterone $\left(\mathrm{P}_{4}\right)$ and oestradiol$17 \beta\left(E_{2}\right)$ in samples taken every three hours (9:00 am to 9:00 pm).

\section{Hormone Assays}

Cortisol analysis. Plasma cortisol was determined by a luminescence immunoassay according to a method previously described (Magnusson et al. 1994). The intra-assay coefficient of variation, calculated from the precision profiles of 5 assays, was below $9.8 \%$ for concentrations of cortisol between 11.6 and $1125.0 \mathrm{nmol} / \mathrm{l}$. The corresponding inter-assay coefficients of variation for 3 quality control samples were $17.8 \%$ (22 $\pm 6 \mathrm{nmol} / \mathrm{l}), 13.1 \%$ $(115 \pm 18 \mathrm{nmol} / \mathrm{l})$ and $10.9 \%(235 \pm 26 \mathrm{nmol} / \mathrm{l})$.

\section{Corticosteroid-binding globulin (CBG)} assay. The binding capacity of CBG was estimated as a 1-point assay and included the addition of cortisol to saturation according to $\mathrm{Ny}$ berg et al. (1988).

Progesterone and oestradiol-17 $\beta$ analysis. $P_{4}$ and $E_{2}$ concentrations were determined by an enzyme immunoassay (Amerlite ${ }^{\circledR}$, Kodak Clinical Diagnostics Ltd., Amersham, England). The kits were used according to the manufacturer's instructions with modifications as described by Rojkittikhun et al. (1993).

The intra-assay coefficient of variation, calculated from the precision profile of 5 assays, was below $2.1 \%$ for concentrations of $\mathrm{P}_{4}$ between 2.0 and $160 \mathrm{nmol} / 1$. The corresponding inter-assay coefficients of variation were $7.5 \%$ and $11.6 \%$ respectively for low and high assay controls.

The intra-assay coefficient of variation, calculated from the precision profiles of 5 assays, was below $5.7 \%$ for concentrations of $E_{2}$ between 5.3 and $362.5 \mathrm{pmol} / \mathrm{l}$. The corresponding inter-assay coefficients of variation were $18.6 \%$ and $11.4 \%$ respectively for low and medium assay controls.

PG-metabolite analysis. 15-Keto-13,14dihydro-PGF ${ }_{2 \alpha}$ (15-ketodihydro- $\mathrm{PGF}_{2 \alpha}$ ), the main initial blood plasma metabolite of prostaglandin $\mathrm{F}_{2 \alpha}$ was analysed by radioimmunoassay as described previously (Granström \& Kindahl 1982, Kunavongkrit et al. 1983). The relative cross-reactions of the antibody were $16.0 \%$ with 15 -keto-PGF ${ }_{2 \alpha} 4.0 \%$ with 13,14 -dihydro$\mathrm{PGF}_{2 \alpha}$ and $0.4 \%$ with $\mathrm{PGF}_{2 \alpha}$. The inter-assay coefficient of variation was $14 \%$ and the intraassay coefficient of variation ranged between $6.6 \%$ and $11.7 \%$ for different ranges of standard curve. The practical sensitivity of the assay for $50 \mu \mathrm{l}$ of plasma was $250 \mathrm{pmol} / \mathrm{l}$.

\section{Embryo Recovery}

On day $17 \pm 1$ of pregnancy, reproductive tracts were removed from sows within 15 to $20 \mathrm{~min}$ of captive-bolt stunning and exsanguination. Reproductive tracts were taken to the laboratory where embryos were recovered within $1 \mathrm{~h}$ of slaughter. The number of corpora lutea was recorded for all sows. An incision was made along the outer curvature of the uterine horn and the embryos were then flushed using saline $(9 \mathrm{~g} / \mathrm{l} \mathrm{NaCl})$. The flushing solution was examined with the aid of a stereomicroscope to count the embryos.

\section{Statistical Analyses}

Changes in $\mathrm{P}_{4}$ and $\mathrm{E}_{2}$ were expressed in percent of individual concentrations on the day before grouping. Data were examined by analysis of variance using the General Linear Model procedure (SAS Institute Inc. 1987). Least-squares means were compared through use of the probability of difference option of SAS. For all anal- 
yses, the variation between sows within rank was used as an error term when testing the differences between ranks.

The model for analysing the between rank differences in concentrations of all the hormones studied included the effects of rank, sow within rank, day, sampling hour, and the interaction between rank and day.

\section{Results}

\section{Behaviour}

Intense fighting occurred between the sows in each group during the first few hours of grouping, and in all the groups a linear dominance hierarchy was established within the first day of grouping. By the second day of grouping, aggression between the sows had decreased and was mainly limited to the time of feeding. During the rank-order test, subordinate sows were always displaced from the feeding troughs by the other 2 sows. The socially intermediate sow was displaced by the dominant sow. The sow labelled dominant always displaced the others. In all the groups, the dominance hierarchy established within the first day of grouping was similar to that seen on the day of the rank-order test, and even on the last day of the experiment. The number of corpora lutea was used as an estimate of ovulation rate, and mean embryo recovery was $66.8 \% \pm 11.5 \%, 71.3 \% \pm 6.0 \%$, $70.0 \% \pm 16.0 \%$ and $69.9 \% \pm 5.8 \%$ for the dominant, intermediate, subordinate, and control sows respectively. No significant differences were detected for this parameter measured.

\section{Hormone Profiles}

As illustrated in Table 1, cortisol concentrations were significantly elevated $(p<0.05)$ on the day of grouping in the dominant (Rank 1), intermediate (Rank 2) and subordinate (Rank 3) sows. The cortisol concentrations that were reached on the day of grouping in the subordinate sows were significantly higher $(\mathrm{p}<0.01)$ than those in the other ranks. Cortisol concentrations on the second and third days of grouping remained similar to those on the first day of grouping in the dominant sows. In the other sows, cortisol levels decreased on the second and third days of grouping, to levels comparable to the pregrouping concentrations in the intermediate sows, but in the subordinate sows these levels were still greater $(p<0.05)$ than the pregrouping concentrations. Cortisol concentrations significantly increased $(p<0.05)$ in the subordinate sows on the day of the rank-order test. Cortisol concentrations did not differ over the days in the control sows. After ACTH administration, plasma cortisol increased $(p<0.001)$ in all sows, but there was no difference in the cortisol concentrations between the ranks or control sows. Total cortisol secretion per $180 \mathrm{~min}$ after ACTH administration (sum of the 15 min samples for $3 \mathrm{~h}$ after ACTH administration) is presented in Table 1.

Corticosteroid-binding globulin (CBG) concentrations were similar between the grouped sows as well as the controls.

In all sows, $\mathrm{P}_{4}$ levels rose gradually $(\mathrm{p}<0.05)$ from the day before grouping to day 15 of pregnancy when the last sample was collected (Table 2).

In all sows, $E_{2}$ levels were unchanged during the experimental period (Table 3 ).

PG-metabolite concentrations (data not shown) were not affected by group-housing.

\section{Discussion}

Elevations in plasma cortisol concentrations occur when unfamiliar pigs are placed together (Arnone \& Dantzer 1980, Warriss \& Brown 1985, Parrott \& Misson 1989, Pedersen et al. 1993). The changes in cortisol concentrations during mixing are more pronounced in subordinate animals (Arnone \& Dantzer 1980). Simi- 
Table 1. Cortısol concentration LSMeans ( \pm SEM) in sows grouped during early pregnancy, and in control sows during the corresponding period.

\begin{tabular}{ccccc}
\hline & \multicolumn{4}{c}{ Cortısol (nmol/1) } \\
\cline { 2 - 5 } Day & Rank 1 & Rank 2 & Rank 3 & Control \\
\hline-1 & $31.6 \pm 30^{\mathrm{a}}$ & $42.7 \pm 3.0^{\mathrm{a}}$ & $34.8 \pm 3.1^{\mathrm{a}}$ & $39.7 \pm 2.4^{\mathrm{a}}$ \\
1 & $45.9 \pm 37^{\mathrm{b} 1}$ & $53.9 \pm 2.6^{\mathrm{b}}$ & $77.5 \pm 28^{\mathrm{b}}$ & $41.9 \pm 2.4^{\mathrm{a} 1}$ \\
2 & $41.4 \pm 2.6^{\mathrm{b}}$ & $417 \pm 30^{\mathrm{a}}$ & $50.3 \pm 2.8^{\mathrm{c}}$ & $43.5 \pm 2.7^{\mathrm{a}}$ \\
3 & $41.0 \pm 4 .^{\mathrm{b}}$ & $38.5 \pm 3.3^{\mathrm{a}}$ & $490 \pm 2.8^{\mathrm{c}}$ & $45.0 \pm 2.5^{\mathrm{a}}$ \\
4 & $38.1 \pm 4.4^{\mathrm{ab}}$ & $45.7 \pm 3.5^{\mathrm{ab}}$ & $639 \pm 3.8^{\mathrm{d}}$ & $428 \pm 2.9^{\mathrm{a}}$ \\
ACTH & $1861 \pm 174$ & $2117 \pm 99.7$ & $2611 \pm 305$ & $2400 \pm 80$ \\
\hline
\end{tabular}

abc Values with different superscripts within the same column differ significantly $(p<0.05$ ).

12 Values with different superscripts within the same row differ significantly.

larly in the present study, fighting for dominance on the first day of grouping resulted in elevation in cortisol concentrations in all grouped sows, which was more marked in the subordinate sows. On subsequent days during grouping, cortisol levels decreased as did the incidence of aggression. Nevertheless, in the dominant and subordinate sows in the present study, the cortisol concentrations on subsequent days during grouping were still higher than the pre-grouping values. These findings concur with those of Parrott \& Misson (1989), supporting psychological stress as an important aspect of the adrenal response to mixing. The presence of another pig, when perceived as a threat, leads to increased pituitary-adrenal activity (Arnone $\&$ Dantzer 1980). Such was not the case in the intermediate ranked sows in the present study, where the cortisol levels on subsequent days durıng grouping were similar to pregrouping levels, suggesting a lower stress response during this period in the intermediate ranked sows. It is not clear why the intermediate ranked sows showed this different response. However, this finding has close parallels to that of MorrowTesch et al. (1994) who used a three-pig model as employed in the present study. Although they did not measure hormone concentrations, Mor-
row-Tesch et al. (1994) found that, compared with socially dominant and subordinate pigs, socially intermediate pigs had lower numbers of circulating neutrophils in the early days of the study. The increase in cortisol concentrations in the intermediate and subordinate sows on the day of the rank order test was due to the repeated aggression as a consequence of repeated concentrate feeding. The dominance hierarchy seen during the rank-order test on the fourth day of grouping in the present study confirmed that observed on the first day of grouping. This suggests that dominance hierarchy was established within the first day of grouping and remained unchanged thereafter. Previous reports have also demonstrated establishment of dominance hierarchy within $24 \mathrm{~h}$ of regrouping pigs (Friend et al. 1983, McGlone 1986). We assessed adrenal function on day 5 of grouping using ACTH challenge test. This test has been used previously in pigs to assess the functional status of the adrenal cortex which may, in turn, reflect the psychological state and experiences of the individual (Mendl et al. 1992). A high response to ACTH is often seen in individuals who have been exposed to certain types of chronic stress lasting 4 to 6 weeks (Dantzer et al. 1983, von Borell \& Ladewig 
Table 2. LSMeans ( \pm SEM) changes (in percent of pregroupıng day values) in plasma $\mathrm{P}_{4}$ levels in primiparous sows grouped during early pregnancy.

\begin{tabular}{ccccc}
\hline \multicolumn{5}{c}{$\% \mathrm{P}_{4}$ levels } \\
\cline { 2 - 5 } Day & Rank 1 & Rank 2 & Rank 3 & Control \\
\hline-1 & $100^{1} \pm 9.7^{\mathrm{a}}$ & $100 \pm 8.7^{\mathrm{a}}$ & $100 \pm 8.7^{\mathrm{a}}$ & $100 \pm 6.0^{\mathrm{a}}$ \\
1 & $117 \pm 9.7^{\mathrm{a}}$ & $121 \pm 8.7^{\mathrm{ab}}$ & $124 \pm 8.7^{\mathrm{ab}}$ & $123 \pm 6.3^{\mathrm{b}}$ \\
2 & $124 \pm 11.8^{\mathrm{b}}$ & $139 \pm 8.7^{\mathrm{b}}$ & $147 \pm 10.2^{\mathrm{b}}$ & $142 \pm 6.8^{\mathrm{bc}}$ \\
3 & $149 \pm 11.9^{\mathrm{b}}$ & $143 \pm 8.7^{\mathrm{b}}$ & $157 \pm 10.2^{\mathrm{b}}$ & $145 \pm 7.1^{\mathrm{bc}}$ \\
4 & $175 \pm 17^{\mathrm{c}}$ & $173 \pm 9.2^{\mathrm{c}}$ & $188 \pm 10.9^{\mathrm{c}}$ & $155 \pm 7.5^{\mathrm{c}}$ \\
\hline
\end{tabular}

$1100 \%$ corresponds to $29.9 \pm 3.2,36.7 \pm 2.8,32.9 \pm 2.8$ and $37.3 \pm 2.6 \mathrm{nmol} / 1$ for the dominant, intermediate, subordinate and control sows, respectively.

abc Values within the same column with different superscripts differ significantly $(p<0.05)$.

1989, Mormede 1990). Similarly, low-ranking animals who have received high levels of aggression from others often show an increased response to ACTH (Sassenrath 1970, Ely \& Henry 1978). In the present study, the cortisol response to ACTH administration in the grouped as well as in the control sows was not significantly different. This may suggest that group housing using the three-pig model where stable linear dominance hierarchies were established, was not stressful enough.

A reduction in plasma corticosteroid-binding capacity after chronic exposure to various environmental or management-related stressors has been reported in the pig (Kattesh et al. 1980, Barnett et al. 1985). In the rat, both dominants and subordinates, particularly the latter, show substantially reduced CBG levels during grouping (Blanchard et al. 1993). The similar pattern of CBG concentrations in the grouped sows and the control sows in the present study suggests that grouping had no influence on CBG concentrations. The decrease in CBG concentrations seen in all sows in the present study coincides with advancement in pregnancy. This finding compares with the situation in the miniature pig, where the alpha globulin fraction, which contains transcortin, decreased during gestation (Tumbleson et al. 1970).
In the present study, no consequences for reproduction, in terms of reproductive hormones and embryonic survival were found in relation to group housing sows during early pregnancy. The patterns of $\mathrm{P}_{4}$ (Shille et al. 1979, King \& Rajamahendran 1988), $\mathrm{E}_{2}$ (Guthrie et al. 1972, Robertson \& King 1974), and PG-metabolite concentrations (Shille et al. 1979) observed in the present study were characteristic of the early pregnant sow. Likewise, the similar embryonic survival observed here between the grouped and the control sows excludes an effect of group housing on embryonic survival in the present study. However, this does not exclude a detrimental effect of social stress during early pregnancy on reproductive performance. Group housing of pregnant sows during the first few weeks of gestation may negatively influence litter size at birth (Bokma 1990). Data for the golden hamster indicate that social stress caused smaller litter sizes in socially subordinate individuals, which was mediated via glucocorticoids (Pratt \& Lisk 1990). In the present study, dominance hierarchy was established on the first day of grouping and remained linear thereafter. When social dominance hierarchy is established within a group, the outcome of subsequent aggressive interactions is predictable from previous encounters, and thus, the level of 
Table 3. LSMeans ( \pm SEM) changes (in percent of pregrouping day values) in plasma $E_{2}$ levels in primiparous sows grouped during early pregnancy.

\begin{tabular}{rrrrr}
\hline \multicolumn{5}{c}{$\% \mathrm{E}_{2}$ levels } \\
\cline { 2 - 5 } Day & \multicolumn{1}{c}{ Rank 1 } & \multicolumn{1}{c}{ Rank 2 } & Rank 3 & \multicolumn{1}{c}{ Control } \\
\hline-1 & $100^{1} \pm 7.3$ & $100 \pm 6.5$ & $100 \pm 6.5$ & $100 \pm 5.9$ \\
1 & $98 \pm 7.3$ & $103 \pm 6.5$ & $101 \pm 6.5$ & $90 \pm 5.9$ \\
2 & $117 \pm 9.0$ & $95 \pm 65$ & $87 \pm 7.7$ & $107 \pm 5.9$ \\
3 & $98 \pm 9.0$ & $102 \pm 6.5$ & $73 \pm 7.7$ & $98 \pm 6.2$ \\
4 & $105 \pm 12.8$ & $123 \pm 6.9$ & $79 \pm 82$ & $96 \pm 6.6$ \\
\hline
\end{tabular}

${ }^{1} 100 \%$ corresponds to $22 \pm 2.4,29.2 \pm 2.1,27.8 \pm 2.1$ and $39 \pm 1.9 \mathrm{pmol} / 1$ for the dominant, intermediate, subord1nate and control sows, respectively.

aggression is reduced within the group (Rowell 1974). This may benefit individual animals because they will avoid potentially costly interactions with conspecifics, whether dominant or subordinate (Rowell 1974, Bernstein 1981). The stability of the three-pig model used in this study may have reduced the level of conflict and stress among the grouped sows, accounting for the similar reproductive performance between the grouped as well as with the control sows. Larger group sizes in pigs have been shown to result in complex, unstable, nonlinear social relationships (McGlone 1986). Among other things, it has been suggested that it is the lack of control and predictability accompanying social instability which stimulates cortisol secretion (Sapolsky 1992). Group housing pregnant sows during early pregnancy using more sows in the group requires further exploration.

\section{Acknowledgements}

This work was supported financially by the Swedish Councll for Forestry and Agricultural Research. Hormone analysis except PG-metabolite was performed at the Department of Clinical Chemistry, Swedish University of Agricultural Sciences.

\section{References}

Arnone M, Dantzer R: Does frustration induce aggression in pigs? Appl. Anım. Ethol., 1980, 6, 351-362.

Barnett JL, Winfield CG, Cronin GM, Hemsworth PH, Dewar AM: The effect of individual and group housing on behavioral and physiological responses related to the welfare of pregnant pigs. Appl. Anım. Behav. Sci., 1985, 14, 149-161.

Bernstein IS Dominance: the baby and the bathwater. Behav. Brain Sc1., 1981, 4, 419-457.

Blanchard DC, Sakal RR, McEwen B, Welss SM, Blanchard RJ Subordination stress: behavioral, brain, and neuroendocrine correlates. Behav. Brain Res., 1993, 58, 113-121.

Bokma S: Housing and management in practicepartly slatted systems. In: Electronic Identıfication in Pig Production. R. Agnic. Soc. England, Monogr. Ser., 1990, No. 10, pp. 37-46.

Bokma S, Kersjes GJK The introduction of pregnant sows in an established group. In Unshelm J, Van Putten G, Zeeb K, Ekesbo I, (eds): Proceedings of the International Congress on Applied Ethology in Farm Anımals, Skara, Sweden. KTBL, Darmstadt, Germany, 1988, pp. 166-169.

Borell von E, Ladewig J. Altered adrenocortical response to acute stressors or ACTH (1-24) in intensively housed pigs. Dom. Anım. Endocrinol., 1989, 6, 299-309.

Christian JJ Social subordınation, population density, and mammalian evolution. Science 1970, $168,84-90$.

Christian JJ, Davis DE: Endocrines, behaviour, and population. Science 1964, 146, 1550-1560.

Dantzer R, Mormede P, Henry JP: Physiological as- 
sessment of adaptation in farm anımals. In: Baxter, SH, Baxter, MR, MacCormack JAC (eds.): Farm Anımal Housing and Welfare, Martinus Nijhoff. The Hague, 1983, pp. 8-19.

Ely DL, Henry JP: Neuroendocrine response patterns in dominant and subordınate mice. Horm. Behav., 1978, 10, 156-169.

Friend TH, Knabe DA, Tanskley TD. Behaviour and performance of pigs grouped by 3 different methods at weanıng. J. Anim. Sci., 1983, 57, 14061411.

Granström E, Kindahl H. Radıoımmunoassay of the major plasma metabolite of $\mathrm{PGF}_{2 \alpha}, 15$-keto13,14-dihydro-PGF ${ }_{2 \alpha}$. Methods Enzymol., 1982, 86, 320-339

Guthrie HD, Henricks DM, Handlin DL P Plasma estrogen, progesterone and luteinizing hormone prior to estrus and during early pregnancy in pigs. Endocrinology 1972, 91, 675-679

Göransson L: Förslag till ny utfodrıngsnorm till suggor. (A proposal for new feed allowances for sows). Fakta Husdjur, Sveriges lantbrukunıversıtet, Uppsala, Sweden, 1984, No. 3.

Kattesh HG, Kornegay ET, Knight JW, Gwazdauskas $F G$, Thomas HR, Notter DR - Glucocorticold concentrations, corticosteroid binding protein characteristics and reproduction performance of sows and gilts subjected to applied stress during midgestation. J. Anım. Sc1., 1980, 50, 897-905.

King GJ, Rajamahendran $R$ Comparison of plasma progesterone profiles in cyclic, pregnant, pseudopregnant and hysterectomized pigs between 8 and 27 days after oestrus. J. Endocr., 1988, 119, 111116.

Kunavongkrit A, Kindahl H, Madej A Clınical and endocrinological studies in primiparous zeroweaned sows. 2. Hormonal patterns of normal cycling sows after zero-weaning. Zbl. Vet. Med. A, 1983, 30, 616-624.

Magnusson U, Holst H, Kindahl H, Karlsson A: Effect of mimickıng prepartum concentration of estradiol-17B on the inflammatory response to endotoxin in gilts. Amer. J. vet. Res., 1994, 55, 785-789.

McGlone JJ: Influence of resources on pig aggression and dominance. Behav. Processes 1986, 12, 135-144.

Mendl M, Zanella AJ, Broom DM: Physiological and reproductive correlates of behavioural strategies in female domestic pıgs. Anım. Behav., 1992, 44, 1107-1121.

Moberg GP: Influence of stress on reproduction: measure of well-being. In: Moberg GP (ed.): Animal stress. Amer. Physiol. Soc., Bethesda, MD 1985, pp. 245-267.

Mormede P: Neuroendocrine responses to social stress. In: Zayan R, Dantzer R (eds.): Social Stress in Domestic Anımals, Kluwer Academıc Publishers. Dordrecht, 1990, pp. 203-211.

Morrow-Tesch JL, McGlone JJ, Salak-Johnson JL. Heat and social stress effects on p1g immune measures. J. Anım. Sc1., 1994, 72, 2599-2609.

Nyberg L, Lundström K, Edfors-Lilja I, Rundgren M Effects of transport stress on concentrations of cortısol, cortıcosteroid-binding globulin and glucocorticold receptors in pigs with different halothane genotypes. J Anım. Sc1., 1988, 66, 12011211.

Parrott RF, Misson $B H^{\cdot}$ Changes in pig salivary cortisol in response to transport simulation, food and water deprivation, and mixing. Br. Vet. J., 1989, 145, 501-505.

Pedersen LJ, Rojkittikhun T, Einarsson S, Edqvist L$E$. Postweaning grouped sows. effects of aggression on hormonal patterns and oestrous behaviour. Appl. Anım. Behav. Sc1., 1993, 38, 25-39.

Pratt NC, Lisk RD. Effects of social stress during early pregnancy on litter size and sex ratio in the golden hamster (Mesocricetus auratus). J. Reprod. Fert1l , 1989, 87, 763-769.

Pratt NC, Lisk RD Dexamethasone can prevent stress-related litter deficits in the golden hamster. Behav. Neural. B1ol., 1990, 54, 1-12.

Robertson HA, Kıng GJ Plasma concentrations of progesterone, oestrone, oestradiol-17 $\beta$ and of oestrone sulphate in the prg at implantation, during pregnancy and at parturition J. Reprod. Fert1l., 1974, 40, 133-141.

Rodriguez H, Kunavongkrit A . Chronic venous catheterization for frequent blood sampling in unrestrained pigs. Acta vet. scand., 1983, 24, 318-320.

Rojkttikhun T, Einarsson S, Zilinskas H, Edqvist LE, Uvnäs-Moberg K, Lundeheim N. Effect of insulin admınıstration at weaning on hormonal patterns and reproductive performance in primiparous sows. J. Vet. Med. A, 1993, 40, 161-168.

Rowell TE The concept of social dominance. Behav. Biol., 1974, 11, 31-154.

Sapolsky $R M \cdot$ Cortisol concentrations and the significance of rank instability among wild baboons. Psychoneuroendocrinology, 1992, 17, 701-709.

SAS Institute Inc · SAS/STAT ${ }^{\circledR}$ Guide for Personal Computers, Version 6 Edition. SAS Institute, Inc., Cary, NC., 1987. 
Sassenrath $E N \cdot$ Increased adrenal responsiveness related to social stress in rhesus monkeys Horm. Behav., 1970, 1, 283-298.

Shille VM, Karlbom I, Einarsson S, Larsson K, Kindahl H, Edqvist L-E Concentrations of progesterone and 15-keto-13,14-dihydroprostaglandin $\mathrm{F}_{2 \alpha}$ in peripheral plasma during the estrous cycle and early pregnancy in gilts. Zbl Vet. Med. A, 1979, 26, 169-181.

Tumbleson MEM, Burks F, Spate MP, Hutcheson DP, Middleton CC. Serum biochemical and hematological parameters of Sinclair (5-1) minıature sows during gestation, lactatıon. Can. J. Comp. Med., 1970, 34, 312-319.

Warriss PD, Brown SN: The physiological response to fightıng in pigs, the consequences for meat quality. J. Sc1. Food Agric., 1985, 36, 87-92.

\section{Sammandrag \\ Hormonella förändringar $i$ samband med gruppe- ring av ungsuggor under tidig dräkttghet}

Effekten av grupperıng under tıdıg dräktıghet av ungsuggor har studerats med avseende på maternella hormonella förändrıngar och fosteröverlevnad hos tjugo ungsuggor av korsnıngsras (Svensk Yorkshire $\times$ Svensk Lantras). På dag $11 \pm 11$ dräktıgheten sammanfördes 3 stycken slumpmässigt utvalda suggor, som inte tıdigare gått tıllsammans, 1 en gemensam box $(3 \mathrm{~m} \times 3 \mathrm{~m})$ medan en fjärde sugga placerades 1 en egen box och fungerade som kontrolldjur. Detta upprepades 5 gånger. Blodprover samlades med början dagen före grupperingen och pågıck till dag 5 efter grupperingen och analyserades med avseende på kortisol, kortıkosteroıd-bındande globulin (CBG), progesteron ( $\mathrm{P} 4)$, östradıol-17 $\beta\left(\mathrm{E}_{2}\right)$ och prostaglan$\operatorname{din} \mathrm{F}_{2 \alpha}$ metaboliten (PG-metabolit). En rangordningstest och en ACTH test utfördes på dag 4 respektive dag 5 efter grupperıngen. Suggorna slaktades på dag $17 \pm 1$ av dräktıgheten och fostren samlades upp. Aggressıoner åtföljd av kortısolstegrıngar $(\mathrm{p}<0,05)$ förekom hos samtliga grupperade suggor första grupperingsdagen. Kortısolstegringarna var högst $(\mathrm{p}<0,01)$ hos de lägst rankade suggorna. Kortısolkoncentratıonerna och agressionsnivåerna minskade under de foljande dagarna, men kortısolnıvåerna var fortfarande högre än före grupperıngen hos samtliga suggor utom hos de mellanrankade suggorna. Kortısolkoncentrationerna efter ACTH testen var lika hos de grupperade suggorna och kontrollsuggorna Rangordnıngen, som fastställts gruppernngsdagen bekräftades vid rangordnıngstesten. Koncentrationerna av $\mathrm{P}_{4}, \mathrm{E}_{2}$, PG-metaboliten och CBG var lika hos de grupperade suggorna och kontrollsuggorna. Medelprocenttalen återfunna foster 1 relation till antalet gula kroppar var $66,8 \pm 11,5$, $71,3 \pm 6,0,70,0 \pm 16,0$ och $69,9 \pm 5,8$ hos de högst, mellan och lägst rankade suggorna respektive hos kontrollsuggorna. Grupperıng av suggor under tıdig dräktıghet hade sålunda ingen inverkan vare sıg på blodkoncentratıonerna av könshormoner eller fosteröverlevnad.

(Recelved December 4, 1995, accepted September 3, 1996).

Reprints may be obtained from: S. Eınarsson, Department of Obstetrics \& Gynaecology, Faculty of Veternary Medicine, Swedısh University of Agricultural Sciences, P.O. Box 7079, S-750 07 Uppsala, Sweden. E-mail: Stig.Einarsson@og.slu.se, fax: +46 (0) 18-673545, tel: +46 (0) 18-672170. 
